\title{
Clustering Tagg Status Facebook Dengan Menggunakan Algoritma K-MEDOIDS
}

\author{
Sefia Candra ${ }^{1}$ \\ sefia_chandra@yahoo.com
}

\author{
Antonius R.C ${ }^{2}$ \\ anton@ti.ukdw.ac.id
}

\author{
Lucia Dwi Krisnawati ${ }^{3}$ \\ krisna@ukdw.ac.id
}

\begin{abstract}
This research is implementing $K$-Medoids algorithm to discover clusters on a friend list of a Facebook user. To find those clusters, the system uses the strongest path which is based on the tag frequency of status update of the facebook user to measure the tie strength from a friend to other friends. The experiments of using 3 clusters, 5 clusters, and 7 clusters, which resulted in average purity score 0.7430. The experiment resulted in rank of highest average purity score, at the first rank is experiment which used 3 clusters with the average score 0.8806 , at the second rank is experiment which used 7 clusters with the average score 0.7114 , and the third rank is experiment which used 5 clusters with the average score 0.6368 .
\end{abstract}

Keywords: cluster, Dijkstra, Facebook, strongest path, K-Medoids, purity, status update, tag

\section{PENDAhUluan}

Facebook merupakan jejaring sosial yang terkenal di dunia yang membantu pengguna untuk menjalin pertemanan yang sangat luas. Pengguna Facebook dapat menjalin pertemanan dengan ratusan bahkan ribuan teman, baik yang dikenal maupun yang tidak. Akan tetapi, ketika pertemanan menjadi begitu besar, akan sangat sulit untuk memilahmilah informasi, informasi mana yang ingin diterima dan yang akan dibagikan ke teman lain. Facebook sendiri berusaha untuk menyelesaikan masalah tersebut dengan meningkatkan fitur dalam daftar pertemanan, yaitu dengan membuat daftar teman dan mengelompokkan teman secara otomatis dan up-to-date berdasarkan informasi pengguna Facebook, seperti berdasarkan sekolah, tempat kerja, keluarga, dan domisili. Namun, pengelompokkan tersebut masih terlalu luas dan tidak dapat menggambarkan suatu kelompok individu yang saling berhubungan baik.

\footnotetext{
${ }^{1}$ Teknik Informatika, Fakultas Teknologi Informasi, Universitas Kristen Duta Wacana, Yogyakarta

${ }^{2}$ Teknik Informatika, Fakultas Teknologi Informasi, Universitas Kristen Duta Wacana, Yogyakarta

${ }^{3}$ Teknik Informatika, Fakultas Teknologi Informasi, Universitas Kristen Duta Wacana, Yogyakarta
} 
Berdasarkan masalah di atas, pada penelitian ini, penulis akan membangun sebuah aplikasi berbasis algoritma K-medoids untuk menemukan cluster-cluster pada daftar teman pengguna Facebook, dengan memanfaatkan frekuensi interaksi tagging pada status update sebagai dasar nilai kedekatan antara satu teman ke teman yang lain.

\section{LANDASAN TEORI}

\subsection{Algoritma Dijkstra}

Algoritma Dijkstra adalah suatu algoritma untuk menemukan jalur terpendek dengan biaya termurah atau jarak terkecil dari sebuah node ke semua node yang ada pada suatu graf berbobot. Jarak dari antar node dilambangkan dengan bobot pada edge yang menghubungkan node bersangkutan. Jarak antar node harus bernilai positif $(>=0)$.

Langkah-langkah algoritma Dijkstra adalah sebagai berikut (The Department of Land Surveying and Geo-Informatics [LSGI], 2011):

1. Set semua nilai jarak. Set 0 untuk node awal dan $\infty$ untuk semua node lain.

2. Tandai semua node sebagai node yang belum dikunjungi dan set node awal sebagai node yang dipilih.

3. Untuk node yang dipilih, tinjau semua node lain yang belum dikunjungi dan hitung jaraknya (dari node awal). Jika jarak yang dihasilkan lebih kecil daripada jarak sebelumnya ganti nilai jarak menjadi hasil perhitungan jarak yang baru.

4. Ketika meninjau semua node lain pada node yang dipilih dan node lain sudah pernah dikunjungi, maka tidak perlu dicek kembali nilai jaraknya karena jarak yang tercatat pada node yang sudah pernah dikunjungi adalah jarak final dan minimal.

5. Set node yang belum pernah dikunjungi yang memiliki jarak terkecil (dari node awal) sebagai node yang dipilih dan ulangi langkah 3.

\subsection{Algoritma Jalur Terkuat}

Hangal et al. (2010) mengusulkan sebuah algoritma untuk menemukan dan menghitung nilai jalur terkuat (strongest path) dari node sumber ke node target pada social network. Jalur terkuat adalah jalur yang memberi nilai pengaruh (influence) tertinggi dari node sumber ke node target. Pengaruh dimodelkan dengan interaksi yang memerlukan biaya atau investasi, seperti waktu dan usaha yang diperlukan. Besarnya investasi yang diberikan (jumlah interaksi) merupakan ukuran informatif dari tie strength. Secara singkat untuk menghitung besarnya influence digunakan rumus berikut.

$$
\text { Influence }(A, B)=\frac{\operatorname{Invests}(B, A)}{\sum_{X} \operatorname{Invests}(B, X)}
$$




\section{Keterangan:}

Influence $(A, B) \quad$ : besarnya pengaruh yang diberikan oleh node $A$ (sumber) kepada node $B$ (target).

Invests $(B, A) \quad: \quad$ total interaksi yang dilakukan dari node $B$ ke node $A$.

$\sum_{x}$ Invests $(B, X)$ : total interaksi yang dilakukan dari node $B$ ke semua node yang ada pada graf.

Untuk menemukan jalur terkuat antar node, Hangal et al. (2010) memodelkannya dengan menggunakan graf berbobot dan berarah, di mana node mewakili aktor (orang), bobot edge mewakili pengaruh, dan arah edge mewakili arah pengaruh. Hangal et al. juga menambahkan sebuah nilai probabilitas konstan berupa discount factor untuk setiap edge karena panjang jalur yang dilalui akan mempengaruhi nilai pengaruh yang diberikan oleh node sumber ke node target. Sebagai contoh sebuah jalur $\mathrm{P}$ dengan panjang $|\mathrm{P}|$ yang terdiri dari edge $\mathrm{e}_{1}, \mathrm{e}_{2}, \ldots, \mathrm{e}_{\mathrm{n}}$ dan sebuah discount factor $\chi$, maka kekuatan dari jalur $\mathrm{P}$ adalah:

$$
\mathrm{S}(P)=\prod D \times \operatorname{Influence}\left(e_{i}\right), e_{i} \in P .
$$

Algoritma ini mengadaptasi algoritma Dijkstra untuk menghitung nilai jalur terkuat antara dua node, node sumber ke node target. Langkah-langkah adaptasi yang dilakukan pada algoritma Dijkstra untuk menghitung jalur terkuat adalah:

- Jalur $P$ adalah jalur dari node sumber ke node target yang dapat memaksimalkan nilai dari rumus [2.2].

- Pada kasus ini, akan dimaksimalkan logaritma pada matriks berikut:

$$
\sum \log (D)+\log \left(\text { Influence }\left(e_{i}\right)\right), e_{i} \in P
$$

- Oleh karena itu, untuk meminimaliskannya menggunakan rumus:

$$
-\sum \log (D)+\log \left(\text { Influence }\left(e_{i}\right)\right), e_{i} \in P
$$

- Akhirnya, meminimaliskan dengan menggunakan rumus berikut ini:

$$
\sum \log (1 / D)+\log \left(1 / \text { Influence }\left(e_{i}\right)\right), e_{i} \in P
$$

Oleh karena itu, dengan menggunakan algoritma Dijkstra dapat dihitung nilai jalur terkuat, di mana bobot edge/jarak pada algoritma Dijkstra adalah hasil perhitungan dari

$$
\log \left(\frac{1}{D}\right)+\log \left(\frac{1}{\text { influence }\left(e_{i}\right)}\right)
$$

Dengan kata lain, semakin rendah total bobot jalur yang dihasilkan oleh algoritma Dijkstra, maka semakin tinggi nilai kekuatan jalurnya. 


\subsection{Algoritma K-medoids}

Algoritma K-medoids atau dikenal pula dengan PAM (Partitioning Around Medoids) menggunakan metode partisi clustering untuk mengelompokkan sekumpulan $n$ objek menjadi sejumlah $k$ cluster. Algoritma ini menggunakan objek pada kumpulan objek untuk mewakili sebuah cluster. Objek yang terpilih untuk mewakili sebuah cluster disebut medoid. Cluster dibangun dengan menghitung kedekatan yang dimiliki antara medoid dengan objek non-medoid.

Menurut Han dan Kamber (2006, hal 406) algoritma K-medoids adalah sebagai berikut.

1. Secara acak pilih $k$ objek pada sekumpulan $n$ objek sebagai medoid.

2. Ulangi:

3. Tempatkan objek non-medoid ke dalam cluster yang paling dekat dengan medoid.

4. Secara acak pilih $o_{\text {acak }}$ : sebuah objek non-medoid.

5. Hitung total biaya, $S$, dari pertukaran medoid $o_{\mathrm{j}}$ dengan $\mathrm{o}_{\text {random }}$.

6. Jika $S<0$ maka tukar $o_{\mathrm{j}}$ dengan $\mathrm{o}_{\text {acak }}$ untuk membentuk sekumpulan $k$ objek baru sebagai medoid.

7. Hingga tidak ada perubahan.

\subsection{Purity}

Menurut Manning, Raghavan, dan Schütze (2009), purity merupakan salah satu ukuran untuk mengukur kualitas clustering berbasis external criterion. External criterion adalah metode untuk mengevaluasi seberapa baik hasil clustering dengan menggunakan sekumpulan kelas acuan sebagai wakil penilaian pengguna, di mana kelas acuan ini diperoleh dari hasil penilaian manusia. Evaluasi ini tidak menggunakan label kelas pada kelas acuan, tetapi hanya menggunakan hasil partisi pada kelas acuan.

Secara formal, untuk menghitung nilai purity dapat digunakan rumus berikut.

$$
\operatorname{purity}(\Omega, \mathbb{C})=\frac{1}{N} \sum_{k} \max _{j}\left|\omega_{k} \cap c_{j}\right|
$$

Keterangan:

$$
\begin{aligned}
& \Omega=\left\{w_{1}, w_{2}, \ldots, w_{k}\right\} \text { adalah kumpulan cluster } \\
& C=\left\{c_{1}, c_{2}, \ldots, c_{j}\right\} \text { adalah kumpulan kelas acuan } \\
& w_{k}=\text { adalah kumpulan objek pada chuster } w_{k} \\
& c_{j}=\text { adalah kumpulan objek pada kumpulan kelas acuan } c_{j}
\end{aligned}
$$


Jika nilai purity semakin mendekati 1 menunjukkan bahwa clustering memberikan hasil yang semakin baik. Sedangkan, jika nilai purity semakin mendekati 0, maka clustering memberikan hasil yang semakin buruk.

\section{HASIL DAN PEMBAHASAN}

\subsection{Contoh Perhitungan Manual Sistem}

\subsubsection{Penyaringan Teman}

Dimisalkan, user $\mathrm{X}$ telah melakukan proses login dan mendapatkan access token berupa xxxx. Kemudian, dari daftar teman Facebook yang dimiliki X, X memilih A, B, C, D, E, F, dan G sebagai teman-teman yang ingin dikelompokkan. Selanjutnya, sistem akan mengirimkan request ke Facebook APIs melalui FQL untuk masing-masing teman. Misalnya untuk teman $\mathrm{A}$, maka request yang dikirimkan adalah https://graph.facebook.com/fql?q=SELECT target_id FROM stream_tag WHERE actor_id=A\&access_token $=\mathrm{xxxx}$.

Berdasarkan hasil pengembalian yang diterima oleh sistem, maka didapatkan frekuensi interkasi tagging pada status update Facebook yang dilakukan antar teman-teman yang telah dipilih oleh X. Data tersebut dapat dilihat pada bagian (a) Gambar 1 (untuk mempermudah penjelasan data ini akan disebut data pada tabel tagging).

Berdasarkan data pada tabel tagging, teman $\mathrm{H}$ pernah dikenai tag oleh $\mathrm{G}$, namun $\mathrm{H}$ tidak pernah melakukan tag ke teman-teman yang lain, maka data pada tabel tagging yang berisikan $\mathrm{H}$ dihapus. Sehingga tabel tagging hanya berisikan data-data seperti pada bagian (b) Gambar 1.

(a)

\begin{tabular}{|c|c|c|}
\hline actor & target & tag \\
\hline A & D & 1 \\
\hline B & E & 1 \\
\hline C & A & 2 \\
\hline D & A & 3 \\
\hline D & C & 2 \\
\hline E & B & 4 \\
\hline E & F & 4 \\
\hline F & E & 3 \\
\hline G & H & 2 \\
\hline
\end{tabular}

(b)

\begin{tabular}{|c|c|c|}
\hline actor & target & tag \\
\hline A & D & 1 \\
\hline B & E & 1 \\
\hline C & A & 2 \\
\hline D & A & 3 \\
\hline D & C & 2 \\
\hline E & B & 4 \\
\hline E & F & 4 \\
\hline F & E & 3 \\
\hline
\end{tabular}

(c)

\begin{tabular}{|c|c|}
\hline $\begin{array}{c}\text { Id_ } \\
\text { friend }\end{array}$ & $\begin{array}{c}\text { derajat } \\
\text { tag }\end{array}$ \\
\hline $\mathrm{A}$ & 2 \\
\hline $\mathrm{B}$ & 1 \\
\hline $\mathrm{C}$ & 1 \\
\hline $\mathrm{D}$ & 1 \\
\hline $\mathrm{E}$ & 2 \\
\hline $\mathrm{F}$ & 1 \\
\hline
\end{tabular}

Gambar 1. Contoh Penyaringan Teman 


\subsubsection{Perhitungan Bobot Edge}

Berdasarkan data pada tabel tagging yang telah melalui proses penyaringan, maka didapatkan influence dari satu teman ke teman yang lain dengan menggunakan rumus [1] seperti pada bagian (a) Gambar 2. Dari hasil perhitungan influence tersebut, dihitung bobot edge dari satu teman ke teman yang lain dengan menggunakan rumus [6] dan discount factor sebesar 0,95 (sama dengan nilai discount factor yang digunakan oleh Hangal et al., 2010). Hasil perhitungan bobot edge dapat dilihat pada bagian (b) Gambar 2 (untuk mempermudah penjelasan data ini akan disebut data pada tabel influence).

\begin{tabular}{|c|c|c|c|c|c|c|c|}
\hline \multicolumn{4}{|c|}{ (a) } & \multicolumn{4}{|c|}{ (b) } \\
\hline souce & target & influence & Keterangan & souce & target & weight & Keterangan \\
\hline A & C & 1 & $\frac{2}{2}$ & A & C & 0,0223 & $\log \left(\frac{1}{0,9 B}\right)+\log \left(\frac{1}{1}\right)$ \\
\hline A & D & 0,6 & $\frac{3}{3+2}$ & A & D & 0,2441 & $\log \left(\frac{1}{0,95}\right)+\log \left(\frac{1}{0,6}\right)$ \\
\hline B & $E$ & 0,5 & $\frac{4}{4+4}$ & B & E & 0,3233 & $\log \left(\frac{1}{0,95}\right)+\log \left(\frac{1}{0,5}\right)$ \\
\hline C & D & 0,4 & $\frac{2}{3+2}$ & C & D & 0,4202 & $\log \left(\frac{1}{0,95}\right)+\log \left(\frac{1}{0,4}\right)$ \\
\hline D & A & 1 & $\frac{1}{1}$ & D & A & 0,0223 & $\log \left(\frac{1}{0,9 b}\right)+\log \left(\frac{1}{1}\right)$ \\
\hline$E$ & B & 1 & $\frac{1}{1}$ & $E$ & B & 0,0223 & $\log \left(\frac{1}{0,95}\right)+\log \left(\frac{1}{1}\right)$ \\
\hline E & $\mathrm{F}$ & 1 & $\frac{3}{3}$ & $E$ & $\mathrm{~F}$ & 0,0223 & $\log \left(\frac{1}{0,95}\right)+\log \left(\frac{1}{1}\right)$ \\
\hline $\mathrm{F}$ & E & 0.5 & $\frac{4}{-2}$ & $\mathrm{~F}$ & E & 0.3233 & $\log \left(\frac{1}{--n}\right)+\log \left(\frac{1}{-1}\right)$ \\
\hline
\end{tabular}

Gambar 2. Contoh Perhitungan Bobot Edge

\subsubsection{Perhitungan Nilai Jalur Terkuat}

Langkah-langkah untuk menghitung jalur terkuat dari satu teman ke teman lain adalah sebagai berikut (untuk mempermudah penjelasan data ini akan disimpan pada tabel strongest):

1. number_weight $=($ jumlah total pada kolom weight table influence $)+1$

$$
\begin{aligned}
= & (0,0223+0,2441+0,3233+0,4202+0,0223+0,0223+0,0223 \\
& +0,3233)+1 \\
= & 2,4001
\end{aligned}
$$

2. $1 \mathrm{~s}=$ Data unik pada kolom target tabel influence $\rightarrow\{\mathrm{A}, \mathrm{B}, \mathrm{C}, \mathrm{D}, \mathrm{E}, \mathrm{F}\}$

3. Lakukan perulangan selama ada data pada ls:

Lakukan perulangan selama ada data pada 1s:

INSERT tabel strongest selama ada data pada ls dengan nilai:

(ls, 1s, 0, number_weight), jika ls $\neq 1 \mathrm{~s}$

(ls, ls, 0, 0), jika ls = ls

4. Lakukan perulangan selama ada data pada ls: 
Implementasi algoritma Dijkstra

Ilustrasi implementasi algoritma Dijkstra dengan ls= A ditunjukkan pada Gambar 3.

\begin{tabular}{|c|c|c|c|c|c|c|c|c|c|c|c|c|c|}
\hline source & target & visited & distance & & sour & ce $\quad$ targe & et & distance & & source & target & visited & distance \\
\hline A & A & 0 & 0 & & A & A & 1 & 0 & & A & A & 1 & 0 \\
\hline A & B & 0 & 2 & & A & B & 0 & \begin{tabular}{|l|l} 
& 2.4001
\end{tabular} & & A & B & 0 & 2.4001 \\
\hline A & c & 0 & 2.4001 & & A & c & 0 & 0.0223 & & A & $c$ & 1 & 0.0223 \\
\hline A & $D$ & 0 & 2.4001 & & A & D & 0 & 0.2441 & & A & $D$ & 0 & 0.2441 \\
\hline A & $E$ & 0 & 2.4001 & & A & $E$ & 0 & 2.4001 & & A & $E$ & 0 & 2.4001 \\
\hline \multirow[t]{8}{*}{ A } & $F$ & 0 & 2.4001 & & A & $\mathrm{F}$ & 0 & 2.4001 & & A & $F$ & 0 & 2.4001 \\
\hline & & & & source & target & \begin{tabular}{|l|} 
visited \\
\end{tabular} & distance & & source & target & visited & distance & \\
\hline & & & & A & A & 1 & 0 & & A & A & 1 & 0 & \\
\hline & & & & A & B & 0 & 2.4001 & & A & B & 1 & 2.4001 & \\
\hline & & & & A & $c$ & 1 & 0.0223 & & A & $c$ & 1 & 0.0223 & \\
\hline & & & & $A$ & $D$ & 1 & 0.2441 & & A & $D$ & 1 & 0.2441 & \\
\hline & & & & A & $E$ & 0 & 2.4001 & & A & $E$ & 1 & 2.4001 & \\
\hline & & & & A & $\mathrm{F}$ & 0 & 2.4001 & & A & $F$ & 1 & 2.4001 & \\
\hline
\end{tabular}

Gambar 3. Ilustrasi Implementasi Algoritma Dijkstra

1. a) Target A dipilih sebagai node terpilih, karena data pada kolom distance merupakan distance terkecil dengan kondisi source $=\mathrm{A}$ dan visited $=0$.

b) Nilai pada kolom visited tabel strongest dengan kondisi source $=\mathrm{A}$ dan target $=\mathrm{A}$ diperbarui menjadi 1.

c) Nilai distance pada target $\mathrm{C}$ diganti dengan nilai distance pada target $\mathrm{A}$ (0) ditambah dengan nilai pada kolom weight tabel influence dengan kondisi source $=\mathrm{A}$ dan target $=\mathrm{C}(0,0223)$, karena nilai tersebut lebih kecil dari pada nilai pada kolom distance tabel strongest dengan kondisi source $=\mathrm{A}$ dan target $=\mathrm{C}$.

d) Nilai distance pada target $\mathrm{D}$ diganti dengan nilai distance pada target $\mathrm{A}$ (0) ditambah dengan nilai pada kolom weight tabel influence dengan kondisi source=A dan target $=\mathrm{D}(0,2441)$, karena nilai tersebut lebih kecil dari pada nilai pada kolom distance tabel strongest dengan kondisi source $=\mathrm{A}$ dan target $=\mathrm{D}$.

2. a) Target $\mathrm{C}$ dipilih sebagai node terpilih, karena data pada kolom distance merupakan distance terkecil dengan kondisi source $=\mathrm{A}$ dan visited $=0$.

b) Nilai pada kolom visited tabel strongest dengan kondisi source $=\mathrm{A}$ dan target $=\mathrm{C}$ diperbarui menjadi 1.

3. a) Target $\mathrm{D}$ dipilih sebagai node terpilih, karena data pada kolom distance merupakan distance terkecil dengan kondisi source $=\mathrm{A}$ dan visited $=0$.

b) Nilai pada kolom visited tabel strongest dengan kondisi source $=\mathrm{A}$ dan target $=\mathrm{D}$ diperbarui menjadi 1. 
4. a) Semua nilai kolom visited diperbarui menjadi 1, karena nilai terkecil pada kolom distance dengan kondisi source $=\mathrm{A}$ dan visited $=0$ sama dengan nilai number_weight (jumlah total pada kolom weight table strongest +1 ).

Hasil akhir nilai jalur terkuat dari satu teman ke teman yang lain merupakan hasil akhir yang tersimpan pada tabel strongest. Hasil akhir pada tabel strongest dapat dilihat pada Gambar 4.

\begin{tabular}{|c|c|c|c|c|c|c|c|}
\hline souce & target & visited & distance & souce & target & visited & distance \\
\hline A & A & 1 & 0 & $\mathrm{D}$ & A & 1 & 0,0223 \\
\hline$A$ & $B$ & 1 & 2,4001 & $\bar{D}$ & $B$ & 1 & 2,4001 \\
\hline$A$ & $\mathrm{C}$ & 1 & 0,0223 & $\mathrm{D}$ & C & 1 & 0,0446 \\
\hline A & D & 1 & 0,2441 & $\mathrm{D}$ & D & 1 & 0 \\
\hline $\bar{A}$ & $E$ & 1 & 2,4001 & $\mathrm{D}$ & $E$ & 1 & 2,4001 \\
\hline$A$ & $\mathrm{~F}$ & 1 & 2,4001 & $\mathrm{D}$ & $F$ & 1 & 2,4001 \\
\hline B & $A$ & 1 & 2,4001 & $E$ & $A$ & 1 & 2,4001 \\
\hline$B$ & $B$ & 1 & 0 & $E$ & $B$ & 1 & 0,0223 \\
\hline$B$ & C & 1 & 2,4001 & $E$ & C & 1 & 2,4001 \\
\hline B & D & 1 & 2,4001 & $\mathrm{E}$ & D & 1 & 2,4001 \\
\hline B & $\mathrm{E}$ & 1 & 0,3233 & $E$ & $\mathrm{E}$ & 1 & 0 \\
\hline$B$ & $F$ & 1 & 0,3456 & $\mathrm{E}$ & $F$ & 1 & 0,0223 \\
\hline C & $A$ & 1 & 0,4425 & $\mathrm{~F}$ & $A$ & 1 & 2,4001 \\
\hline $\mathrm{C}$ & $B$ & 1 & 2,4001 & $\mathrm{~F}$ & $B$ & 1 & 0,3456 \\
\hline $\mathrm{C}$ & C & 1 & 0 & $\mathrm{~F}$ & C & 1 & 2,4001 \\
\hline $\mathrm{C}$ & $\mathrm{D}$ & 1 & 0,4202 & $F$ & $\mathrm{D}$ & 1 & 2,4001 \\
\hline C & $\mathrm{E}$ & 1 & 2,4001 & $\mathrm{~F}$ & $\mathrm{E}$ & 1 & 0,3233 \\
\hline C & $F$ & 1 & 2,4001 & $\mathrm{~F}$ & $F$ & 1 & 0 \\
\hline
\end{tabular}

Gambar 4. Hasil Akhir Tabel Strongest

\subsubsection{Pengelompokkan Teman Menggunakan Algoritma K-Medoids}

Misalnya daftar teman yang telah melalui proses penyaringan di atas akan dikelompokkan menjadi dua cluster, maka langkah-langkah yang akan dilakukan sistem sebagai berikut:

1. Diambil dua teman dengan derajat tag tertinggi (dapat dilihat pada bagian (c) Gambar 3.1), sehingga dipilih A sebagai medoid cluster pertama $\left(\mathrm{C}_{1}\right)$ dengan derajat tag 2 yang berasal dari $\mathrm{C}$ dan $\mathrm{D}$ serta $\mathrm{E}$ sebagai medoid cluster kedua $\left(\mathrm{C}_{2}\right)$ dengan derajat tag 2 yang berasal dari B dan F.

Berdasarkan nilai pada kolom distance tabel strongest, maka didapatkan hasil cluster: $\mathrm{C}_{1}=\{\mathrm{A}, \mathrm{C}, \mathrm{D}\}$ dan $\mathrm{C}_{2}=\{\mathrm{E}, \mathrm{B}, \mathrm{F}\}$

Total jarak adalah $\left(S_{\text {lama }}\right)=\{(\mathrm{A}, \mathrm{A})+(\mathrm{A}, \mathrm{C})+(\mathrm{A}, \mathrm{D})+(\mathrm{E}, \mathrm{E})+(\mathrm{E}, \mathrm{B})+(\mathrm{E}, \mathrm{F})\}$

$$
=0+0,0223+0,2441+0+0,0223+0,0223=0,2910
$$

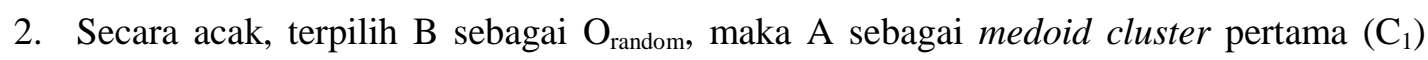
dan B sebagai medoid cluster kedua $\left(\mathrm{C}_{2}\right)$.

Maka didapatkan hasil cluster: $\mathrm{C}_{1}=\{\mathrm{A}, \mathrm{C}, \mathrm{D}\}$ dan $\mathrm{C}_{2}=\{\mathrm{B}, \mathrm{E}, \mathrm{F}\}$

Total jarak adalah $\left(S_{\text {baru }}\right) \quad=\{(\mathrm{A}, \mathrm{A})+(\mathrm{A}, \mathrm{C})+(\mathrm{A}, \mathrm{D})+(\mathrm{B}, \mathrm{B})+(\mathrm{B}, \mathrm{E})+(\mathrm{B}, \mathrm{F})\}$ $=0+0,0223+0,2441+0+0,0223+0,3456=0,6343$ 
Karena $S_{\text {baru }}>S_{\text {lama }}$, maka tidak ada pertukaran medoid.

3. Lakukan kembali langkah 2 hingga semua teman non-medoid terpilih menjadi $\mathrm{O}_{\text {random }}$ dan tidak terjadi perubahan pada medoid.

\subsection{Pengujian Sistem}

Data yang digunakan dalam pengujian sistem adalah mutual friends yang dimiliki oleh tiga pemilik akun Facebook, yaitu Anthony Andrian (ID Facebook 1360992359), Antonius Tornado (ID Facebook 1255512315), dan Gustin Lawis (ID Facebook 1616770571). Berdasarkan tiga akun tersebut didapatkan 175 mutual friends. Kemudian dilakukan pengiriman request dengan menggunakan FQL (Facebook Query Language) ke Facebook APIs untuk mendapatkan data frekuensi tag yang pernah dilakukan antar mutual friends (pengambilan data mutual friends dan frekuensi tag dilakukan tanggal 26 April 2012 20:50). Berdasarkan data frekuensi tag yang didapatkan, tersaring 67 mutual friends, yaitu teman-teman yang pernah melakukan tag ke mutual friends yang lain.

Kemudian penulis melakukan diskusi dengan ketiga pemilik akun untuk melakukan pengelompokkan secara manual terhadap 67 mutual friends tersebut. Pengelompokkan dilakukan dengan mengelompokkan 67 mutual friends tersebut menjadi 3, 5, dan 7 kelompok. Hasil pengelompokkan ini akan digunakan sebagai kelas acuan untuk menghitung nilai purity sistem, di mana untuk setiap jumlah kelompok akan dilakukan tiga kali percobaan dikarenakan terdapat unsur random pada iterasi algoritma K-Medoids. Hasil pengelompokkan disajikan pada Gambar 5, Gambar 6, dan Gambar 7.

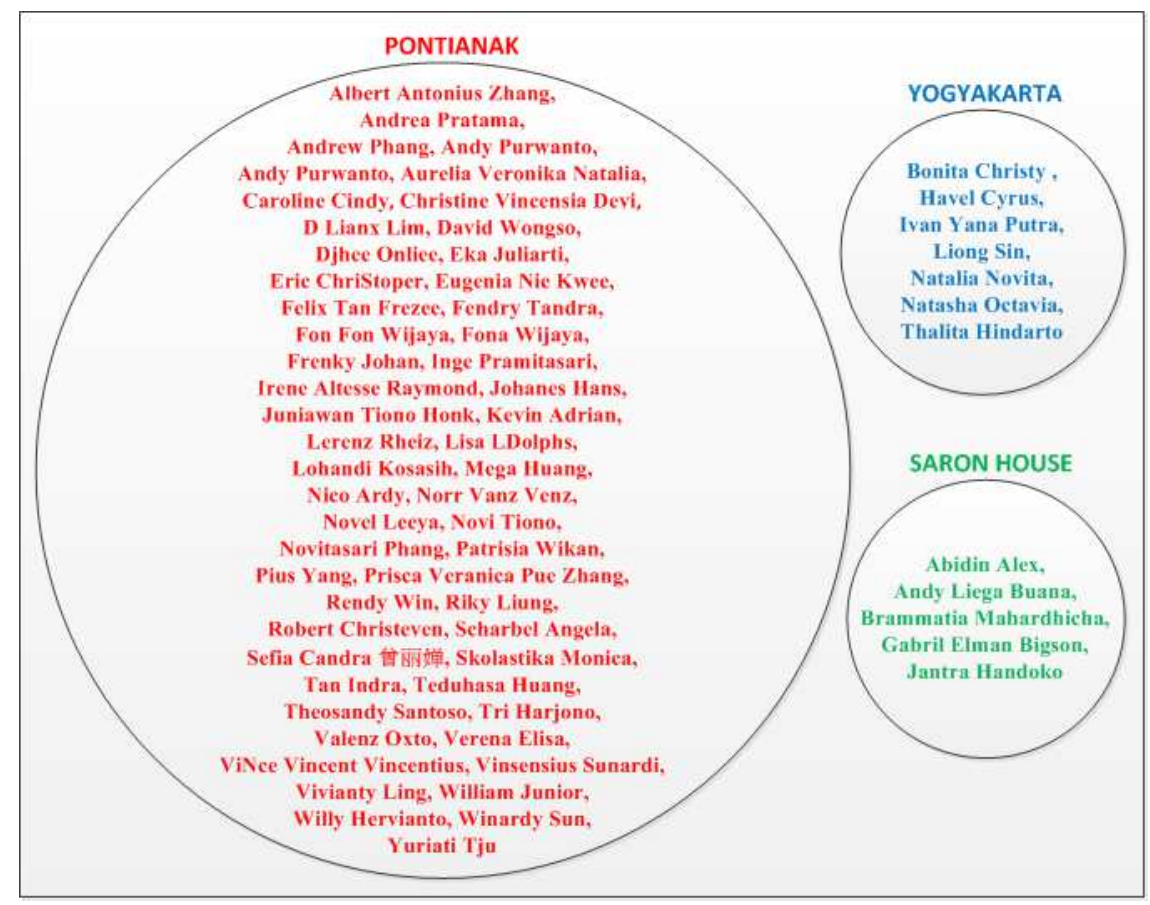

Gambar 5. Kelas Acuan dengan Tiga Kelompok 


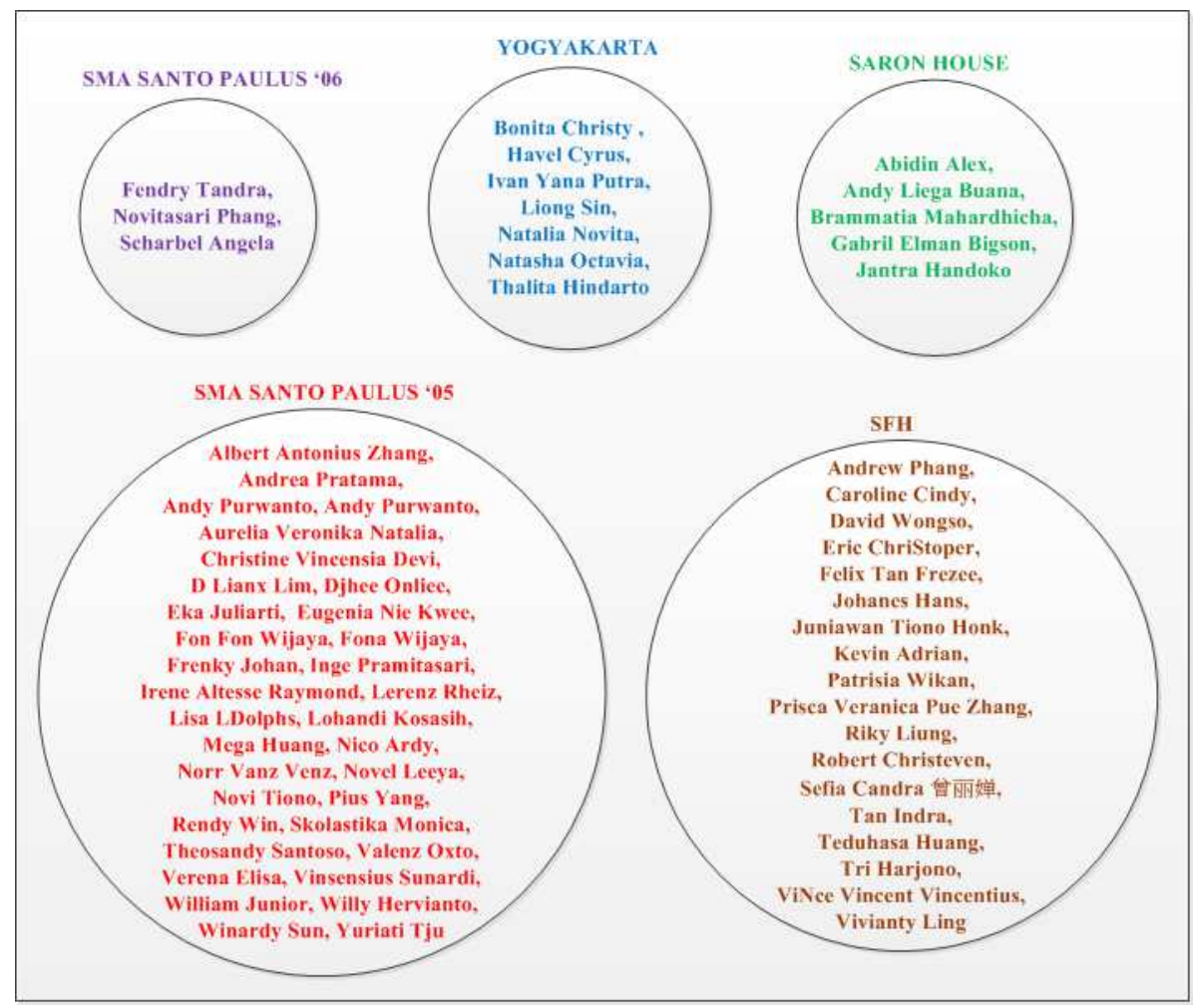

Gambar 6. Kelas Acuan dengan Lima Kelompok

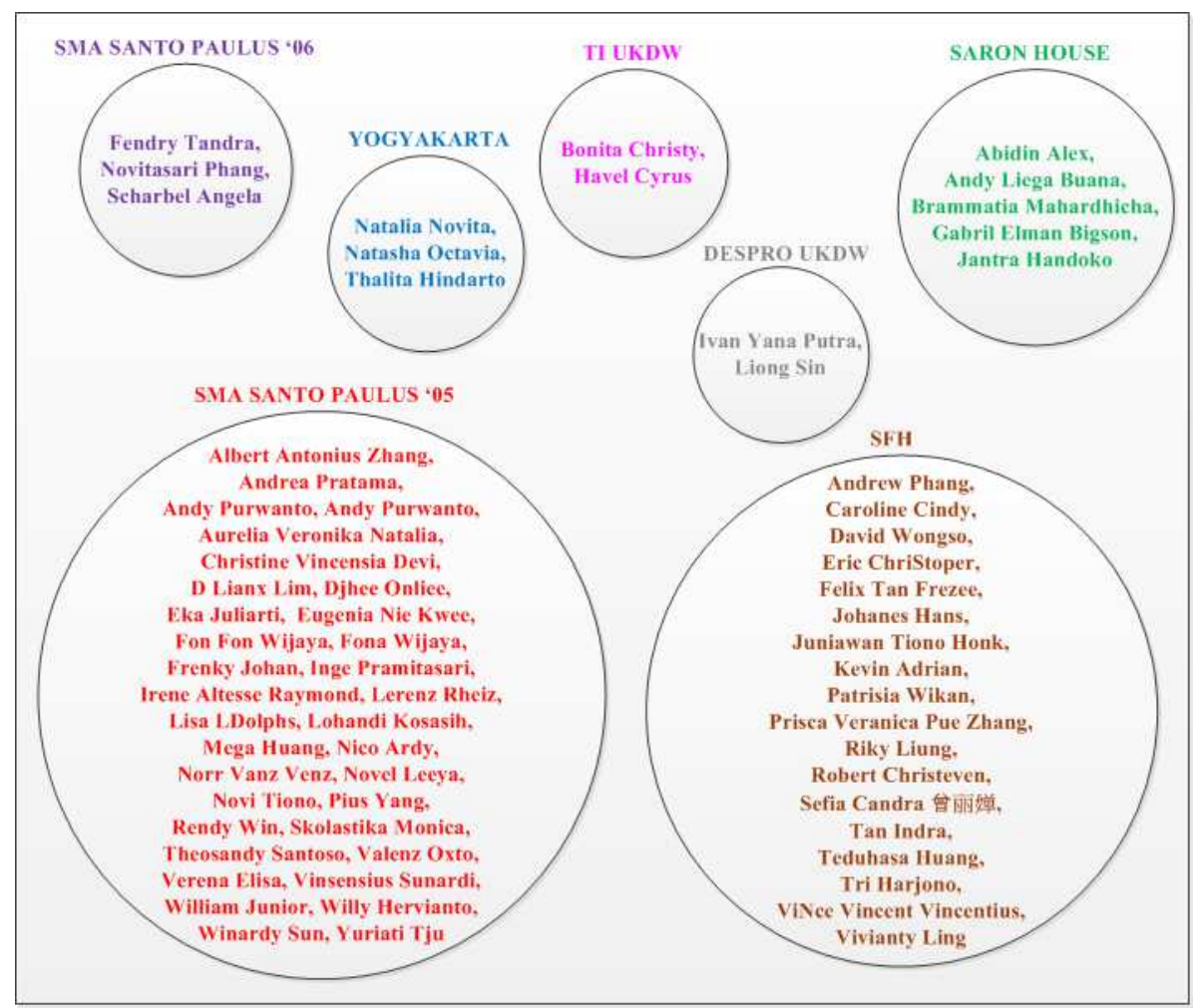

Gambar 7. Kelas Acuan dengan Tujuh Kelompok 
Berdasarkan pengujian yang telah dilakukan, didapatkan rata-rata purity untuk masing-masing jumlah cluster seperti pada Tabel 1.

Tabel 1.

Rata-Rata Purity Hasil Pengujian

\begin{tabular}{|c|c|c|c|}
\hline Jumlah Cluster & Pengujian Ke- & Purity & Rata-Rata Purity \\
\hline \multirow{3}{*}{1} & 1 & 0,8806 & \multirow{3}{*}{0,8806} \\
\hline & 2 & 0,8806 & \\
\hline & 3 & 0,8806 & \\
\hline \multirow{3}{*}{2} & 1 & 0,6269 & \multirow{3}{*}{0,6368} \\
\hline & 2 & 0,6269 & \\
\hline & 3 & 0,6567 & \\
\hline \multirow{3}{*}{3} & 1 & 0,7164 & \multirow{3}{*}{0,7114} \\
\hline & 2 & 0,6866 & \\
\hline & 3 & 0,7313 & \\
\hline \multicolumn{3}{|c|}{ Rata-Rata } & 0,7430 \\
\hline
\end{tabular}

\section{Kesimpulan}

Berdasarkan analisis dan implementasi sistem, maka diperoleh kesimpulan sebagai berikut:

a) Dengan menggunakan algoritma K-Medoids dan nilai jalur terkuat yang didapatkan dari frekuensi tag pada status update sebagai nilai kedekatan antar teman, sistem telah mampu menemukan cluster-cluster dalam daftar teman Facebook dengan baik.

b) Dengan uji coba menggunakan jumlah cluster sebanyak 3, 5, dan 7 didapatkan ratarata nilai purity 0,7430 .

c) Peringkat rata-rata nilai purity tertinggi, yaitu tiga jumlah cluster dengan rata-rata 0,8806, tujuh jumlah cluster dengan rata-rata 0,7114 , dan lima jumlah cluster dengan rata-rata 0,6368 .

\section{Daftar Pustaka}

CodePlex. JSON.Net Serialize All The Things. (2012). Diakses 19 Maret 2012, dari http://json.codeplex.com.

Hangal, S., MacLean, D., Lam, M. S., \& Heer J. (2010). All Friends are Not Equal: Using Weights in Social Graphs to Improve Search. Diakses 19 Maret 2012, dari http://xenon.stanford.edu/ hangal/weighted-socialgraphs.pdf.

Han, J., \& Kamber, M. (2006). Data Mining Concepts and Techniques Second Edition. San Fransico: Morgan Kaufmann Publishers.

Lange, R., Dvornik, T., Hamilton, W., \& Hess B. (n.d.). Data Mining for Facebook Cliques. Diakses 26 Februari 2012, dari http://www.amphro.com/560_Mine_Cliques_Final.pdf. 
Lanzi, P., L., (2009). Clustering: Partitioning Methods. Diakses 01 Mei 2012, dari http://www.pierlucalanzi.net/wp-content/teaching/dmtm/DMTM0809-07-ClusteringPartitioning.pdf.

LSGI. (2011). Shortest Path Algorithm. Diakses 08 April 2012, dari http://www.lsgi.polyu.edu.hk/staff/Bo.Wu/teaching/lsgi521/11-

12/lsgi521_lecture_slides/LSGI521_L6_Spatial\%20Analysis\%20in\%20GIS_Part2_BW.pdf.

Manning, C. D., Raghavan, P., Schütze, H. (2009). An Introduction to Information Retrieval. England: Cambridge University Press.

Safitri, A., \& Hardani, W. (Ed.). (2005). Aljabar Linear Elementer Versi Aplikasi. Diakses 4 April 2012, dari http://books.google.co.id/books?id=v57mQQcr1L8C\&pg=PA193\&lpg=PA193\&dq=clique+adalah\&source $=$ bl\&ots=TX6Ief2fEA\&sig=80Sn7QuVRBod8Ze06a-

ofLRn8\&hl=id\&sa=X\&ei=1p6T4uhCYKIrAfuwYinAg\&ved=0CGEQ6AEwCQ\#v=onepage \&q\&f=false.

TechTarget. (2008). Facebook Status. Diakses 3 April 2012, dari http://whatis.techtarget.com/definition/facebook-status.html.

Wibisono, Y. (2011). Perbandingan Partition Around Medoids (PAM) dan K-Means Clustering Untuk Tweets. Diakses $23 \quad$ Maret 2012, dari http://cs.upi.edu/uploads/yudiwbs/Yudi_Wibisono_UPI_Perbandingan\%20Clustering\%20PAM\%20dan\%20 KMeans\%20untuk\%20Posting\%20Tweet.pdf. 